\title{
Use of Pulp Mill Ash as a Substrate Component for Greenhouse Production of Marigold
}

\author{
Guihong $\mathrm{Bi}^{2}$ and Williams B. Evans \\ Truck Crops Branch Experiment Station, Mississippi State University, 2024 \\ Experiment Station Road, P.O. Box 231, Crystal Springs, MS 39059
}

\author{
Glenn B. Fain ${ }^{1}$ \\ Department of Horticulture, 101 Funchess Hall, Auburn University, \\ AL 36849
}

Additional index words. media, peatmoss, growth index

\begin{abstract}
Pulp mill ash was evaluated as a substrate component in the production of greenhouse-grown French marigold (Tagetes patula L. 'Janie Deep Orange'). Peat-based substrates (75:10:15 by volume blend of peatmoss, vermiculite, and perlite) amended with $0 \%$ to $50 \%$ (by volume) pulp mill ash were compared with a standard commercially available substrate. With the exception of an unfertilized control, each substrate blend contained $5.93 \mathrm{~kg} \cdot \mathrm{m}^{-3} 14 \mathrm{~N}-6.2 \mathrm{P}-11.6 \mathrm{~K}$ (3- to 4 -month release) and $0.89 \mathrm{~kg} \cdot \mathrm{m}^{-3} \mathrm{Micro}-$ max. Substrates containing higher volumes of ash had finer particles, less air space, and more waterholding capacity than the commercial substrate. Bulk density increased with increasing ash volume, and substrate containing $50 \%$ ash had $120 \%$ greater bulk density than the commercial substrate. Substrates containing ash generally had higher $\mathbf{p H}$ and electrical conductivity (EC) than the commercial substrate with substrate $\mathbf{p H}$ and EC increasing with increasing ash volume. In general, marigold plants grown in peat-based substrates with the addition of $0 \%$ to $50 \%$ ash had similar growth indices, flower dry weights, numbers of flowers, and SPAD values as plants grown in commercial substrate; however, plants grown in substrates containing $30 \%$ to $50 \%$ ash had lower shoot dry weights or root quality ratings than plants grown in commercial substrate. Plant growth index, shoot dry weight, and root quality rating decreased with increasing ash volume.
\end{abstract}

Growing substrates constitute one of the largest costs to growers in the greenhouse and nursery industries. Peatmoss is the primary component of many of these substrates, although it is associated with substantial transportation costs and is a nonreadily renewable resource. In the last few decades, as interest in recycling and waste use has increased, researchers have studied a wide range of potential peat alternatives, including many agricultural, industrial, and consumer

\footnotetext{
Received for publication 1 Oct. 2008. Accepted for publication 21 Nov. 2008.

This work was funded by the Mississippi Agricultural and Forestry Experiment Station Special Research Initiative.

We thank Anthony Witcher, Peter Hudson, and Laura Rayburn for technical assistance and Georgia Pacific Company (Lawrence County, MS) for ash material. Contribution of the Mississippi Agricultural and Forestry Experiment Station Journal article no. J-11461.

Mention of a trademark, proprietary product, or vendor does not constitute a guarantee or warranty of the product by the U.S. Department of Agriculture and does not imply its approval to the exclusion of other products or vendors that may also be suitable.

${ }^{1}$ Formerly with the USDA-ARS Southern Horticultural Laboratory, Poplarville, MS 39470.

${ }^{2}$ To whom reprint requests should be addressed; e-mailgb250@msstate.edu.
}

waste byproducts. A number of these materials have demonstrated the potential to replace peatmoss or serve as substrate amendments. These include substrate components made from tree or wood residues (Conover and Poole, 1983; Fain et al., 2006, 2008; Gruda and Schnitzler, 2001; Kenna and Whitcomb, 1985; Wright and Browder, 2005), cotton gin compost (Cole et al., 2005; Jackson et al., 2005; Owings, 1993), vermicompost (Bachman and Metzger, 1998; Hidalgo et al., 2006), municipal waste compost (Bugbee and Frink, 1989; Chong, 2005), and many other waste byproducts.

Pulp mill boiler ash is a widely available industrial waste byproduct produced when the paper industry burns tree residues and other materials to fuel paper mill boilers. The ash has been shown to have a high $\mathrm{pH}$ and the ability to raise soil alkalinity (Demeyer et al., 2001). Muse and Mitchell (1995) reported boiler ash from 19 mills in Alabama had an average $\mathrm{pH}$ of 9.9 , electrical conductivity (EC) of $3.1 \mathrm{dS} \cdot \mathrm{m}^{-1}, 0.45 \%$ total nitrogen, $0.3 \%$ total phosphorus $(\mathrm{P}), 1.3 \%$ potassium $(\mathrm{K})$, and $12.0 \%$ calcium $(\mathrm{Ca})$ and over $50 \%$ of a given sample passed through a $0.106-\mathrm{mm}$ sieve. Currently, the majority of this boiler ash is put into landfills, whereas some is applied to forest and agricultural land. Previous land application studies have shown that boiler ash can increase field soil $\mathrm{pH}$ (Chirenji and Ma, 2002; Muse and Mitchell,
1995); increase extractable soil P, K, Ca, and magnesium $(\mathrm{Mg})$ concentrations (Muse and Mitchell, 1995); increase EC (Chirenji and $\mathrm{Ma}, 2002)$; and increase waterholding capacity and reduce soil bulk density of a fine sand (Chirenji and Ma, 2002). Although some studies have demonstrated that ash applications have negative or no effects on plant growth (Demeyer et al., 2001), most field studies indicated that the application of boiler and other wood ash to soil can improve plant growth, yield, or both (Demeyer et al., 2001; Muse and Mitchell, 1995; Myers and Kopecky, 1998; Rakala and Jozefek, 1990).

In the United States, more than $80 \%$ of boiler ash is disposed of in landfills (Vance, 1996). However, landfill disposal costs are increasing and it is becoming more difficult to acquire new sites for disposal (Demeyer et al., 2001). It is possible that boiler ash can be used as a substrate amendment in greenhouse and nursery production while reducing substrate costs and alleviating some problems pulp mill operators confront when using current methods of disposal. However, peatbased greenhouse and nursery substrates differ significantly from field soils, and plants may respond differently to ash applications. Using marigold as a test plant, the objective of this study was to evaluate the potential of using pulp mill boiler ash as an alternative substrate component for greenhouse production.

\section{Materials and Methods}

Substrate treatments, plant material, and sampling. Studies were conducted in a greenhouse at the Mississippi State University Truck Crops Branch Experiment Station in Crystal Springs, MS (lat. 31 $59^{\prime} \mathrm{N}$, long. $\left.90^{\circ} 21^{\prime} \mathrm{W}\right)$. Pulp mill boiler ash was obtained from a Georgia-Pacific Company craft and corrugated paper mill in Lawrence County, MS. Seven peat-based substrates (75:10:15 by volume of peatmoss, vermiculite, and perlite) amended with $0 \%$ to $50 \%$ (by volume) pulp mill ash and a standard commercially available substrate (Fafard 3B; Conrad Fafard, Inc., Agawam, MA) were evaluated (Table 1). With the exception of an unfertilized control (Substrate 2, A0N; Table 1), each substrate blend contained $5.93 \mathrm{~kg} \cdot \mathrm{m}^{-3}$ 14N-6.2P-11.6K (Osmocote ${ }^{\circledR}$ 3-4 months; Scotts-Sierra Horticultural Products Co., Marysville, $\mathrm{OH}$ ) and $0.89 \mathrm{~kg} \cdot \mathrm{m}^{-3}$ Micromax $^{\circledR}$ (Scotts-Sierra Horticultural Products Co.). Surfactant Aqua-Gro ${ }^{\circledR}$ L (a.i. 99\% alkoxylated polyols; Aquatrols, Paulsboro, NJ) at a rate of $78 \mathrm{~mL} \cdot \mathrm{m}^{-3}$ was added to the peatbased substrates during blending. Dolomitic limestone $\left(2.97 \mathrm{~kg} \cdot \mathrm{m}^{-3}\right)$ was added only to substrates 2 and 3 (A0N and A0; Table 1) because Fafard 3B already contains dolomitic limestone, and substrates 4 to 8 (A10, A20, A30, A40, A50) contain ash, which has a basic $\mathrm{pH}$ that has the potential to elevate substrate $\mathrm{pH}$.

French marigold (Tagetes patula L. 'Janie Deep Orange') seedlings were transplanted from a standard 1206 cell pack into round azalea plastic pots [(one plant/pot) $(15 \mathrm{~cm}$ 
Table 1. Composition of substrate blends used in Expt. 1 and Expt. 2 to assess the effects of pulp mill ash on growth and nutrient composition of greenhouse-grown 'Janie Deep Orange' French marigold.

\begin{tabular}{lcccccc}
\hline & & \multicolumn{3}{c}{ Base components $^{\mathrm{z}}$} & & \\
\cline { 2 - 5 } Treatment & Substrate abbreviation & Fafard 3B & Peat & Ash & Fertilizer Blend $^{\mathrm{y}}$ & Lime $^{\mathrm{x}}$ \\
\hline 1 & Fafard 3B & $100 \%$ & - & - & + & - \\
2 & A0N & - & $100 \%$ & - & - & + \\
3 & A0 & - & $100 \%$ & - & + & + \\
4 & A10 & - & $90 \%$ & $10 \%$ & + & - \\
5 & A20 & - & $80 \%$ & $20 \%$ & + & - \\
6 & A30 & - & $70 \%$ & $30 \%$ & + & - \\
7 & A40 & - & $60 \%$ & $40 \%$ & + & - \\
8 & A50 & - & $50 \%$ & $50 \%$ & + & - \\
\hline
\end{tabular}

${ }^{2}$ Percentage (by volume) of Fafard 3B, peat ( $75: 10: 15$ by volume blend of peatmoss, vermiculite, and perlite), and pulp mill ash in substrate blends.

${ }^{y}$ Fertilizer blend $=5.93 \mathrm{~kg} \cdot \mathrm{m}^{-3}$ Osmocote $(14 \mathrm{~N}-6.2 \mathrm{P}-11.6 \mathrm{~K})$ and $0.89 \mathrm{~kg} \cdot \mathrm{m}^{-3}$ Micromax mixed into substrate before planting.

${ }^{\mathrm{x}} \mathrm{Lime}=2.97 \mathrm{~kg} \cdot \mathrm{m}^{-3}$ dolomitic limestone mixed into substrate before planting. o.d., $11 \mathrm{~cm}$ height, $1327 \mathrm{~cm}^{3}$ volume)] (AZE0600, ITML Horticultural Products, Inc., Brantford, Ontario, Canada) on 5 Apr. 2007 (Expt. 1) and 18 Sept. 2007 (Expt. 2).

All plants were placed on benches in a single-layer polycarbonate greenhouse $\left(16^{\circ} \mathrm{C}\right.$ night temperature $/ 24{ }^{\circ} \mathrm{C}$ vent temperature) arranged in a completely randomized design with each treatment unit (pot) replicated 10 times for each substrate treatment and hand-watered (10\% leaching) as needed. For both experiments, plants were harvested 5 weeks after transplanting. At harvest, leaf greenness (chlorophyll content) was quantified using a SPAD-502 Chlorophyll Meter (Minolta Camera Co., Ramsey, NJ). For each plant, three recently fully expanded leaves were randomly chosen for SPAD measurement and the average of the three readings was recorded. Plant growth index [(height + widest width + perpendicular width) $\div 3$ ] and number of fully open flowers were also recorded. Plant height was measured from medium surface to the tallest plant part. Plants were removed from their containers and root quality was assessed using a 0 to 5 scale with 0 indicating no visible roots on the bottom or side surfaces of the root ball and 5 indicating visible roots were matted on the bottom and on a major portion of the sides of the exposed root ball. The aboveground portions of plants were cut off at the surface of the substrate and separated into shoots (stems and leaves) and flowers. The samples were placed into a $60{ }^{\circ} \mathrm{C}$ forced-air oven and dried to constant weight. Dry weight was recorded for each tissue type.

Tissue nutrient analyses. Five replications of shoot tissue from each substrate treatment in Expt. 1 were ground with a Wiley mill (40 mesh; Thomas Scientific, Swedesboro, NJ) for nutrient analysis. Tissue nutrient analyses were conducted in the Mississippi State University Soil Testing Laboratory (Mississippi State, MS). Total nitrogen (N) was determined by Kjeldahl analysis (Schuman et al., 1973). Concentrations of other nutrients were determined after ashing $1.0 \mathrm{~g}$ oven dry material at $500{ }^{\circ} \mathrm{C}$ for $4 \mathrm{~h}$ (Jones and Steyn, 1973). For determination of sulfur (S), boron (B), iron $(\mathrm{Fe})$, manganese $(\mathrm{Mn})$, copper $(\mathrm{Cu})$, and zinc $(\mathrm{Zn})$, the ash was dissolved in 1.0 $\mathrm{mL}$ 1:1 hydrochloric acid: distilled water before adding $50 \mathrm{~mL}$ of $0.05 \mathrm{~N} \mathrm{HCl}$. To analyze for $\mathrm{P}, \mathrm{K}, \mathrm{Ca}$, and $\mathrm{Mg}$, a second solution was made by adding $9.5 \mathrm{~mL}$ of Lancaster extractant (Cox, 2001) to $0.5 \mathrm{~mL}$ of the first solution. Nutrient concentrations in the solution were determined by inductively coupled plasma emission spectrometry 4300 Optima DV (PerkinElmer Instruments, Norwalk, CT).

Substrate physical property measurements. Substrate physical characteristics were determined at the USDA-ARS Southern Horticultural Laboratory in Poplarville, MS. Substrates from Expt. 1 were analyzed for particle size distribution by passing a $100 \mathrm{~g}$ air-dried sample through $9.50,6.35,3.35$, $2.36,2.0,1.4,1.0,0.50,0.25,0.11$, and $0.05-\mathrm{mm}$ sieves with particles $\leq 0.05 \mathrm{~mm}$ collected in a pan (Fain et al., 2008). Sieves were shaken for 3 min with a Ro-Tap (RoTap RX-29; W.S. Tyler, Mentor, OH) sieve shaker (278 oscillations. $\mathrm{min}^{-1}, 159$ taps $\left.\cdot \min ^{-1}\right)$. Substrate air space at container capacity, waterholding capacity, and total porosity were determined using the procedures described in Bilderback et al. (1982). Substrate bulk density was determined from $347.5-\mathrm{cm}^{3}$ samples dried in a $105{ }^{\circ} \mathrm{C}$ forcedair oven for $48 \mathrm{~h}$.

Substrate $\mathrm{pH}$ and electrical conductivity measurements. Substrate $\mathrm{pH}$ and $\mathrm{EC}$ were measured at 0 and $15 \mathrm{~d}$ after planting (DAP) (Expt. 1) or 0 and 20 DAP (Expt. 2). EC was directly measured using the Field Scout ${ }^{\circledR}$ Soil EC Probe \& Meter (Spectrum Technologies, Inc., Plainfield, IL) (Scoggins and van Iersel, 2006), and $\mathrm{pH}$ was directly measured using the IQ $150 \mathrm{pH}$ Meter (Spectrum Technologies, Inc., Plainfield, IL). Plants were watered to saturation and then allowed to drain for $30 \mathrm{~min}$ before measurements of EC and $\mathrm{pH}$.

Statistical analyses. Data were analyzed by analysis of variance using Statistica (Statsoft, Inc., Tulsa, OK). Comparisons of means among treatments were conducted using Tukey's honestly significant difference test at $P<0.05$. Substrate characteristics and plant response to ash were evaluated using linear and quadratic polynomial contrasts based on the ash volume in the peat-based substrate.

\section{Results and Discussion}

Substrate physical and chemical properties. The ash used in this study had an initial $\mathrm{pH}$ of 8.3 (1:1 weight:volume water extract) and contained $0.47 \%$ total $\mathrm{N}, 0.17 \%$ total $\mathrm{P}$, $0.24 \% \mathrm{~K}, 3.21 \% \mathrm{Ca}, 0.38 \% \mathrm{Mg}, 0.05 \% \mathrm{~S}$, 2006 ppm Fe, 1414 ppm Mn, 387.4 ppm $\mathrm{Zn}, 22.8 \mathrm{ppm} \mathrm{Cu}$, and $39.4 \mathrm{ppm} \mathrm{B}$. An independent laboratory report indicated that the ash from the Lawrence County site contained $452 \mathrm{ppm}$ sodium, $1.5 \mathrm{ppm}$ barium, $45 \mathrm{ppb}$ cadmium $(\mathrm{Cd}), 95 \mathrm{ppb}$ lead $(\mathrm{Pb}), 11$ ppb silver, and no detectible levels of arsenic (As), chromium, mercury ( $\mathrm{Hg}$ ), or selenium (Se). The concentrations of the regulated metals $\mathrm{Cu}, \mathrm{As}, \mathrm{Cd}, \mathrm{Pb}, \mathrm{Hg}$, $\mathrm{Se}$, and $\mathrm{Zn}$ were well below the ceiling concentration allowed for land application of biosolids (US Environmental Protection Agency, 1993).

Substrates containing higher volumes of ash had a higher percentage of fine particles (data not shown). This higher percentage of fine particles is reflected in the differences observed in substrate air space, waterholding capacity, and bulk density (Table 2).
Table 2. Physical properties of substrates used in Expt. 1 to assess the effects of pulp mill ash on growth and nutrient composition of greenhouse-grown 'Janie Deep Orange' French marigold.

\begin{tabular}{ccccc}
\hline Substrate $^{\mathrm{z}}$ & $\begin{array}{c}\text { Air space } \\
(\%)\end{array}$ & $\begin{array}{c}\text { Waterholding capacity } \\
(\%)\end{array}$ & $\begin{array}{c}\text { Total porosity } \\
(\%)\end{array}$ & $\begin{array}{c}\text { Bulk density } \\
\left(\mathrm{g} \cdot \mathrm{cm}^{-3}\right)\end{array}$ \\
\hline Fafard 3B & 20.3 & 63.1 & 83.4 & 0.132 \\
A0N & 21.5 & 66.5 & 88.0 & 0.108 \\
A0 & 20.0 & 65.2 & 85.3 & 0.137 \\
A10 & 18.3 & 71.2 & 89.5 & 0.146 \\
A20 & 17.7 & 70.4 & 88.1 & 0.177 \\
A30 & 12.6 & 72.8 & 85.3 & 0.246 \\
A40 & 13.5 & 72.6 & 86.2 & 0.235 \\
A50 & 13.9 & 69.6 & 83.6 & 0.290 \\
HSD $_{0.05}{ }^{y}$ & 3.1 & 4.8 & 2.9 & 0.018 \\
Contrasts $^{\mathrm{x}}$ & $\mathrm{L}^{* * *}, \mathrm{Q}^{* *}$ & Ash rate response (A0, A10, A20, A30, A40, A50) & $\mathrm{L}^{* * *}, \mathrm{Q} * * *$ \\
\hline
\end{tabular}

${ }^{\mathrm{z}}$ Fafard $3 \mathrm{~B}=100 \%$ Fafard 3B; peat-based substrate blends containing 0\% (A0, A0N), 10\% (A10), 20\% (A20), 30\% (A30), 40\% (A40), and 50\% (A50) pulp mill ash. All substrates contained $5.93 \mathrm{~kg} \cdot \mathrm{m}^{-3}$ Osmocote $(14 \mathrm{~N}-6.2 \mathrm{P}-11.6 \mathrm{~K})$ and $0.89 \mathrm{~kg} \cdot \mathrm{m}^{-3}$ Micromax except A0N. A0 and A0N also contained 2.97 $\mathrm{kg} \cdot \mathrm{m}^{-3}$ dolomitic limestone.

yTukey's honestly significant difference $(P=0.05, \mathrm{n}=3)$.

${ }^{x}$ Significant linear $(\mathrm{L})$ or quadratic $(\mathrm{Q})$ contrasts at $P \leq 0.05(*), 0.01(* *)$, or $0.001(* * *)$ across ash contents $(0 \%$ to $50 \%)$ in peat-based substrates (A0, A10, A20, A30, A40, A50). 
In general, substrates containing ash had less air space, more waterholding capacity, and higher bulk density than the standard commercially available substrate used in this study (Fafard 3B) (Table 2). Substrates containing $0 \%$ to $20 \%$ ash (A0, A10, A20) had more air space than substrates containing $30 \%$ to $50 \%$ ash (A30, A40, A50). Substrates containing $10 \%$ to $40 \%$ ash (A10, A20, A30, A40) had greater waterholding capacity than substrate containing no ash (A0). Substrate containing $10 \%$ ash (A10) had greater total porosity than substrates containing $30 \%$ to $50 \%$ ash (A30, A40, A50). Bulk density increased with increasing ash content (Table 2). Substrate containing $50 \%$ ash (A50) had $120 \%$ greater bulk density than the commercial substrate (Fafard 3B). This high bulk density could potentially pose problems in shipping and handling.

Plant growth. In both experiments, marigold plants grown in peat-based substrates with fertilizer and $0 \%$ to $50 \%$ ash (A0, A10, A20, A30, A40, A50) had similar growth indices (GI), flower dry weights, numbers of flowers, and SPAD values as plants grown in commercial substrate with fertilizer (Fafard 3B) (Tables 3 and 4). Marigolds grown in $40 \%$ and $50 \%$ ash in Expt. 1 (A40, A50) and $50 \%$ ash in Expt. 2 (A50) had lower shoot dry weight, and plants grown in $30 \%$ to $50 \%$ ash in Expt. 1 (A30, A40, A50) and 40\% and 50\% ash in Expt. 2 (A40, A50) had lower root quality ratings than plants grown in commercial substrate (Fafard 3B).

In both experiments, plant growth index, shoot dry weight, and root rating decreased with increasing ash content. Additionally, in Expt. 1, SPAD values decreased with increasing ash content and in Expt. 2, flower dry weight and number of flowers decreased with increasing ash content. There was no significant difference in flower dry weight (Expt. 1) and SPAD reading (Expt. 2) among the substrates with different ash contents (A0, A10, A20, A30, A40, A50). Marigold plants grown in peat-based substrate with no addition of fertilizer $(\mathrm{A} 0 \mathrm{~N})$ had the smallest GI, flower and shoot dry weights, numbers of flowers, root quality ratings, and SPAD readings.

Substrate $p H$ and electrical conductivity. At 0 DAP, substrates containing $10 \%$ to $50 \%$ ash in Expt. 1 (A10, A20, A30, A40, A50) or substrates containing $20 \%$ to $50 \%$ ash in Expt. 2 (A20, A30, A40, A50) had higher $\mathrm{pH}$ than the commercial substrate (Fafard 3B) (Table 5). Substrates containing 30\% to $50 \%$ ash in both experiments (A30, A40, A50) had higher EC than the commercial substrate (Table 5). At 15 DAP (Expt. 1) or 20 DAP (Expt. 2), all substrates containing $20 \%$ to $50 \%$ ash (A20, A30, A40, A50) had higher $\mathrm{pH}$ and $\mathrm{EC}$ than the commercial substrate (Fafard 3B).

In general, $\mathrm{pH}$ and $\mathrm{EC}$ increased with increasing ash content in both experiments at both 0 DAP and 15 or 20 DAP (Table 5). In Expt. 1, at both 0 DAP and 15 DAP, substrate containing $30 \%$ to $50 \%$ ash (A30, A40, A50) had higher $\mathrm{pH}$ than substrate containing $0 \%$ to $10 \%$ ash (A0, A10). At 0 DAP, substrate containing $30 \%$ and $50 \%$ ash (A30, A50) had higher EC than substrate containing no ash (A0). In Expt. 2, at both 0 and 20 DAP, substrates containing $20 \%$ to $50 \%$ ash (A20, $\mathrm{A} 30, \mathrm{~A} 40, \mathrm{~A} 50$ ) had higher $\mathrm{pH}$ than substrates containing $0 \%$ to $10 \%$ ash (A0, A 10 ).

Although nearly all rates of ash in both experiments elevated the substrate $\mathrm{pH}$ and EC (especially at 0 DAP) above the range recommended for most container substrates ( $\mathrm{pH} 5.0$ to 6.5 ; EC 0.5 to $1.0 \mathrm{dS} \cdot \mathrm{m}^{-1}$ for plants fertilized with controlled-release fertilizer only) (Robbins and Evans, 2008; Yeager

et al., 2007), marigold growth characteristics appeared little changed by ash additions of below 30\%. Research using waste byproducts, including spent mushroom compost, turkey litter compost, paper mill sludge, municipal waste compost, and many others, also showed that despite the initial high $\mathrm{pH}$ (up to 8.9) and EC in most waste-derived substrates, there was little or no discernible effect on plant growth of many woody deciduous nursery species (Chong, 2005). The initial elevated EC value in substrates amended with waste byproducts normally declined rapidly after potting as a result of

Table 3. Means of plant growth index (GI), flower dry weight (DW), shoot dry weight (DW), number of flowers per plant, root rating, and SPAD value of 'Janie Deep Orange' French marigold (Expt. 1) grown for $35 \mathrm{~d}$ in substrates containing different proportions of pulp mill ash.

\begin{tabular}{ccccccc}
\hline Substrate $^{\mathrm{z}}$ & GI $(\mathrm{cm})^{\mathrm{y}}$ & Flower DW $(\mathrm{g})$ & Shoot DW $(\mathrm{g})$ & $\begin{array}{c}\text { Flower } \\
\text { number }\end{array}$ & $\begin{array}{c}\text { Root } \\
\text { rating }^{\mathrm{x}}\end{array}$ & $\begin{array}{c}\text { SPAD-502 } \\
\text { value }^{\mathrm{w}}\end{array}$ \\
\hline Fafard 3B & 22.8 & 3.1 & 6.1 & 7.6 & 4.0 & 48.8 \\
A0N & 15.4 & 1.2 & 1.2 & 3.2 & 2.8 & 44.8 \\
A0 & 22.9 & 3.2 & 5.4 & 7.5 & 4.0 & 48.0 \\
A10 & 24.2 & 2.7 & 6.2 & 6.3 & 3.9 & 47.3 \\
A20 & 24.0 & 3.0 & 6.8 & 6.5 & 3.8 & 46.3 \\
A30 & 22.5 & 2.6 & 5.0 & 6.6 & 3.6 & 46.3 \\
A40 & 21.6 & 2.6 & 4.5 & 7.5 & 3.6 & 46.6 \\
A50 & 22.4 & 3.0 & 4.7 & 7.9 & 3.4 & 45.3 \\
HSD $^{v}$ & 2.1 & 1.0 & 1.2 & 2.2 & 0.3 & 3.8
\end{tabular}

Contrasts $^{\mathrm{u}} \quad \mathrm{L}^{* *} \quad$ NS $\quad \mathrm{L}^{* * *}, \mathrm{Q}^{* *} \quad \mathrm{Q}$,

${ }^{\mathrm{z}}$ Fafard $3 \mathrm{~B}=100 \%$ Fafard 3B; peat-based substrate blends containing $0 \%(\mathrm{~A} 0, \mathrm{~A} 0 \mathrm{~N}), 10 \%(\mathrm{~A} 10), 20 \%$ (A20), 30\% (A30), 40\% (A40), and 50\% (A50) pulp mill ash. All substrates contained $5.93 \mathrm{~kg} \cdot \mathrm{m}^{-3}$ Osmocote $(14 \mathrm{~N}-6.2 \mathrm{P}-11.6 \mathrm{~K})$ and $0.89 \mathrm{~kg} \cdot \mathrm{m}^{-3}$ Micromax except A0N. A0 and A0N also contained 2.97 $\mathrm{kg} \cdot \mathrm{m}^{-3}$ dolomitic limestone.

yPlant growth index $=[($ height + width + perpendicular width $) \div 3]$.

${ }^{x}$ Root rating on a scale of 0 to 5 in which $0=$ no roots visible on the surfaces of root ball and $5=$ visible roots were matted on the bottom and on a major portion of the sides of the exposed root ball.

${ }^{\text {w }}$ SPAD reading using SPAD-502 chlorophyll meter (average of three leaves per plant).

vTukey's honestly significant difference $(P=0.05, \mathrm{n}=10)$.

uSignificant linear (L) or quadratic (Q) contrasts at $P \leq 0.05(*), 0.01(* *)$, or $0.001(* * *)$ across ash contents $(0 \%$ to $50 \%)$ in peat-based substrates (A0, A10, A20, A30, A40, A50).

$\mathrm{NS}=$ nonsignificant.

Table 4. Means of growth index (GI), flower dry weight (DW), shoot dry weight (DW), number of flowers per plant, root rating, and SPAD value of 'Janie Deep Orange' French marigold (Expt. 2) grown for 35 $\mathrm{d}$ in substrates containing different proportions of pulp mill ash.

\begin{tabular}{ccccccc}
\hline Substrate $^{\mathrm{z}}$ & $\begin{array}{c}\text { GI } \\
(\mathrm{cm})^{\mathrm{y}}\end{array}$ & $\begin{array}{c}\text { Flower } \\
\text { DW }(\mathrm{g})\end{array}$ & $\begin{array}{c}\text { Shoot } \\
\text { DW }(\mathrm{g})\end{array}$ & $\begin{array}{c}\text { Flower } \\
\text { number }\end{array}$ & $\begin{array}{c}\text { Root } \\
\text { rating }^{\mathrm{x}}\end{array}$ & $\begin{array}{c}\text { SPAD-502 } \\
\text { value }^{\mathrm{w}}\end{array}$ \\
\hline Fafard 3B & 27.4 & 4.8 & 7.9 & 11.7 & 4.2 & 41.5 \\
A0N & 18.0 & 1.2 & 1.7 & 4.2 & 3.4 & 35.4 \\
A0 & 27.3 & 5.0 & 7.7 & 12.8 & 4.2 & 41.7 \\
A10 & 27.1 & 4.5 & 7.6 & 10.4 & 4.3 & 40.8 \\
A20 & 26.7 & 4.5 & 7.1 & 11.3 & 4.0 & 40.8 \\
A30 & 26.6 & 4.1 & 6.9 & 9.4 & 3.9 & 40.1 \\
A40 & 26.4 & 4.0 & 6.7 & 10.0 & 3.6 & 40.7 \\
A50 & 25.5 & 3.9 & 6.1 & 9.9 & 3.5 & 41.3 \\
HSD $^{v}$ & 2.5 & 1.0 & 1.3 & 3.3 & 0.5 & 3.3
\end{tabular}

Contrasts $^{\mathrm{u}} \quad \mathrm{L}^{*} \quad \mathrm{~L}^{* * *} \quad \mathrm{~L}^{* * *} \quad \mathrm{~L}^{* *} \quad \mathrm{~L}^{* * *}$

${ }^{\mathrm{z}}$ Fafard $3 \mathrm{~B}=100 \%$ Fafard 3B; peat-based substrate blends containing 0\% (A0, A0N), 10\% (A10), 20\% (A20), 30\% (A30), 40\% (A40), and 50\% (A50) pulp mill ash. All substrates contained $5.93 \mathrm{~kg} \cdot \mathrm{m}^{-3}$ Osmocote $(14 \mathrm{~N}-6.2 \mathrm{P}-11.6 \mathrm{~K})$ and $0.89 \mathrm{~kg} \cdot \mathrm{m}^{-3}$ Micromax except A0N. A0 and A0N also contained 2.97 $\mathrm{kg} \cdot \mathrm{m}^{-3}$ dolomitic limestone.

yPlant growth index $=[$ (height + width + perpendicular width $) \div 3]$.

${ }^{x}$ Root rating on a scale of 0 to 5 in which $0=$ no roots visible on the surfaces of root ball and $5=$ visible roots were matted on the bottom and on a major portion of the sides of the exposed root ball.

${ }^{\text {w}} \mathrm{SPAD}$ reading using SPAD-502 chlorophyll meter (average of three leaves per plant).

vTukey's honestly significant difference $(P=0.05, \mathrm{n}=10)$.

uSignificant linear (L) or quadratic (Q) contrasts at $P \leq 0.05(*), 0.01(* *)$, or $0.001(* * *)$ across ash contents $(0 \%$ to $50 \%)$ in peat-based substrates (A0, A10, A20, A30, A40, A50).

NS $=$ nonsignificant. 
the salts leaching from the containers through irrigation water (Chong, 2005). In this study, the declined substrate EC values were observed in both experiments at 15 or 20 DAP. Although the effects of ash on $\mathrm{pH}$ will likely limit its suitability as an amendment for acid-requiring plants such as rhododendrons (Rhododendron spp.) and azalea (Azabe suitable for plants such as geranium (Geranium spp.), daylilies (Hemerocallis spp.), and carnation (Dianthus spp.), which prefer a $\mathrm{pH}$ in the 6.5 to 7.0 range (Robbins and Evans, 2008).

Tissue nutrient concentrations. In general, plants grown in substrates containing ash (A10, A20, A30, A40, A50) had similar K concentrations in shoots but higher $\mathrm{Ca}, \mathrm{S}$, and $\mathrm{B}$ and lower $\mathrm{Mg}$ concentrations than plants grown in commercial substrate (Table 6). lea spp.), substrates amended with ash might

Compared with plants grown in commercial substrate (Fafard 3B), plants grown in substrates containing $20 \%$ and $50 \%$ (A20, A50) ash had lower $\mathrm{N}$ concentration in shoots, and plants grown in $20 \%$ to $50 \%$ ash (A20, A30, $\mathrm{A} 40, \mathrm{~A} 50)$ had lower $\mathrm{P}$ concentrations. In contrast, plants grown in substrates containing $40 \%$ ash (A40) had higher Fe concentrations in shoots, plants grown in $10 \%$ ash (A10) had higher $\mathrm{Zn}$ concentrations, plants grown in $10 \%$ and $20 \%$ ash (A10, A20) had higher $\mathrm{Cu}$ concentrations and plants grown in $10 \%$ and $30 \%$ to $50 \%$ ash (A10, A30, A40, A50) had higher Mn concentration. It is of note that compared with plants grown in commercial substrate (Fafard 3B), plants grown in peat-based substrate without ash (A0) had similar $\mathrm{N}, \mathrm{K}$, and $\mathrm{Fe}$, but higher $\mathrm{Ca}$, $\mathrm{S}, \mathrm{Mn}, \mathrm{Zn}, \mathrm{Cu}$, and $\mathrm{B}$ and lower $\mathrm{P}$ and $\mathrm{Mg}$ concentrations in shoots, suggesting

Table 5. Means of $\mathrm{pH}$ and electrical conductivity $(\mathrm{EC})\left(\mathrm{dS} \cdot \mathrm{m}^{-1}\right)$ of substrates used in Expt. 1 and Expt. 2 to assess the effects of pulp mill ash on growth and nutrient composition of greenhouse-grown 'Janie Deep Orange' French marigold.

\begin{tabular}{|c|c|c|c|c|c|c|c|c|}
\hline \multirow[b]{3}{*}{ Substrate $^{z}$} & \multicolumn{4}{|c|}{ Expt. 1} & \multicolumn{4}{|c|}{ Expt. 2} \\
\hline & \multicolumn{2}{|c|}{0 DAP } & \multicolumn{2}{|c|}{15 DAP } & \multicolumn{2}{|c|}{0 DAP } & \multicolumn{2}{|c|}{20 DAP } \\
\hline & $\mathrm{pH}$ & $\overline{\mathrm{EC}}$ & $\mathrm{pH}$ & $\overline{E C}$ & $\mathrm{pH}$ & $\overline{\mathrm{EC}}$ & $\mathrm{pH}$ & $\overline{\mathrm{EC}}$ \\
\hline Fafard 3B & 6.16 & 0.70 & 6.31 & 0.26 & 6.02 & 0.80 & 5.94 & $\overline{0.22}$ \\
\hline $\mathrm{A} 0 \mathrm{~N}$ & 5.96 & 0.65 & 6.34 & 0.53 & 5.89 & 0.23 & 6.32 & 0.22 \\
\hline A0 & 5.76 & 0.75 & 5.68 & 0.57 & 5.33 & 1.07 & 5.48 & 0.28 \\
\hline A 10 & 6.79 & 1.08 & 6.54 & 0.67 & 6.23 & 1.21 & 6.05 & 0.43 \\
\hline A20 & 7.32 & 1.13 & 7.37 & 0.84 & 6.81 & 1.26 & 6.75 & 0.57 \\
\hline A 30 & 7.53 & 1.37 & 7.72 & 1.09 & 7.19 & 1.41 & 6.78 & 0.83 \\
\hline A40 & 7.58 & 1.17 & 7.50 & 1.12 & 7.26 & 1.58 & 7.08 & 1.10 \\
\hline A50 & 7.84 & 1.23 & 7.87 & 1.24 & 7.18 & 1.70 & 7.06 & 1.38 \\
\hline $\mathrm{HSD}^{\mathrm{y}}$ & 0.45 & 0.43 & 0.47 & 0.43 & 0.55 & 0.60 & 0.65 & 0.32 \\
\hline \multicolumn{9}{|c|}{ Ash rate response $(\mathrm{A} 0, \mathrm{~A} 10, \mathrm{~A} 20, \mathrm{~A} 30, \mathrm{~A} 40, \mathrm{~A} 50)$} \\
\hline
\end{tabular}

${ }^{\mathrm{z}}$ Fafard 3B $=100 \%$ Fafard 3B; peat-based substrate blends containing 0\% (A0, A0N), 10\% (A10), 20\% (A20), 30\% (A30), 40\% (A40), and 50\% (A50) pulp mill ash. All substrates contained $5.93 \mathrm{~kg} \cdot \mathrm{m}^{-3}$ Osmocote $(14 \mathrm{~N}-6.2 \mathrm{P}-11.6 \mathrm{~K})$ and $0.89 \mathrm{~kg} \cdot \mathrm{m}^{-3}$ Micromax except A0N. A0 and A0N also contained 2.97 $\mathrm{kg} \cdot \mathrm{m}^{-3}$ dolomitic limestone.

y Tukey's honestly significant difference $(P=0.05, \mathrm{n}=10)$.

${ }^{x}$ ignificant linear (L) or quadratic (Q) contrasts at $P \leq 0.05(*), 0.01(* *)$, or $0.001(* * *)$ across ash contents $(0 \%$ to $50 \%)$ in peat-based substrates (A0, A10, A20, A30, A40, A50).

$\mathrm{DAP}=$ days after planting. that some of the differences in tissue nutrient concentrations between plants grown in ash-containing substrates and those in Fafard 3B may not have been caused by the addition of ash, but by differences between the Fafard $3 \mathrm{~B}$ and the blended peat-based substrates.

There was no significant difference in $\mathrm{N}$, $\mathrm{K}$, and $\mathrm{S}$ concentrations in shoots from plants grown in peat-based substrates with different ash content (A0, A10, A20, A30, A40, A50) (Table 6). Compared with plants grown in peat-based substrate containing no ash (A0), plants grown in all substrates containing ash had lower $\mathrm{Mg}, \mathrm{Zn}$, and $\mathrm{Cu}$ concentrations in shoots; and plants grown in $20 \%$ to $50 \%$ ash (A20, A30, A40, A50) had lower Mn concentrations. In contrast, plants grown in 30\% and 40\% ash (A30, A40) had higher $\mathrm{Ca}$ concentrations, plants grown in $40 \%$ ash (A40) had higher $\mathrm{Fe}$ concentrations, and plants grown in 10\% ash (A10) had higher B concentrations.

Plants growing in a high $\mathrm{pH}$ substrate are subject to nutrient imbalances as a result of changes in nutrient availability as $\mathrm{pH}$ increases in the substrate. With marigold, addition of ash to the substrate might elevate $\mathrm{Ca}$ uptake at the expense of $\mathrm{Mg}$ uptake, as suggested by Reed (1996). Increasing ash additions also led to lower $\mathrm{Mn}, \mathrm{Zn}$, and $\mathrm{B}$ concentrations in shoots, although concentrations of these nutrients were higher than those measured in the commercial substrate.

Like with many other alternative substrates, it appears paper mill boiler ash has the potential to be used as an ingredient in peat-based substrates rather than as a sole substrate component. Research on municipal solid waste compost (MSWC) has shown blends of up to $33 \%$ in growing substrate produced similar plant growth compared with growth in a potting mix with no MSWC (Wright et al., 2005). A study of substrates blended with a combination of biosolids and yard-trimming compost also found $40 \%$

Table 6. Mean nutrient concentration in shoots (stems and leaves) of 'Janie Deep Orange' French marigold (Expt. 1) grown for 35 d in substrates containing different proportions of pulp mill ash.

\begin{tabular}{|c|c|c|c|c|c|c|c|c|c|c|c|}
\hline \multirow[b]{3}{*}{ Substrate $^{z}$} & \multicolumn{11}{|c|}{ Concn } \\
\hline & $\mathrm{N}$ & $\mathrm{P}$ & $\mathrm{K}$ & $\mathrm{Ca}$ & $\mathrm{Mg}$ & $\mathrm{S}$ & $\mathrm{Fe}$ & $\mathrm{Mn}$ & $\mathrm{Zn}$ & $\mathrm{Cu}$ & $\mathrm{B}$ \\
\hline & \multicolumn{6}{|c|}{ - $(\%)^{-}$} & \multicolumn{5}{|c|}{ 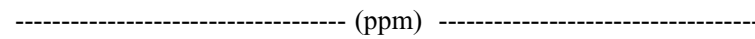 } \\
\hline Fafard 3B & 3.06 & 0.61 & 3.30 & 0.87 & 0.72 & 0.36 & 47.2 & 29.8 & 20.2 & 3.2 & 23.2 \\
\hline $\mathrm{A} 0 \mathrm{~N}$ & 2.21 & 0.06 & 2.11 & 1.18 & 0.53 & 0.78 & 30.0 & 153.2 & 37.6 & 5.8 & 59.4 \\
\hline A0 & 2.73 & 0.40 & 3.82 & 1.24 & 0.56 & 0.81 & 48.0 & 164.6 & 42.6 & 7.6 & 41.2 \\
\hline A 10 & 2.55 & 0.47 & 3.78 & 1.42 & 0.34 & 0.78 & 47.2 & 174.2 & 32.6 & 5.4 & 50.0 \\
\hline A 20 & 2.28 & 0.36 & 3.34 & 1.52 & 0.30 & 0.60 & 47.0 & 59.7 & 23.3 & 5.0 & 45.0 \\
\hline A30 & 2.56 & 0.37 & 3.71 & 1.60 & 0.35 & 0.74 & 45.8 & 69.0 & 22.0 & 3.0 & 42.4 \\
\hline A40 & 2.86 & 0.35 & 3.54 & 1.65 & 0.36 & 0.75 & 66.2 & 88.6 & 23.8 & 3.8 & 45.4 \\
\hline A50 & 2.41 & 0.29 & 3.53 & 1.41 & 0.34 & 0.69 & 49.2 & 66.4 & 22.6 & 2.6 & 40.6 \\
\hline \multirow[t]{2}{*}{$\mathrm{HSD}^{\mathrm{y}}$} & 0.59 & 0.14 & 0.90 & 0.28 & 0.12 & 0.20 & 17.0 & 34.9 & 8.7 & 1.4 & 6.4 \\
\hline & \multicolumn{11}{|c|}{ Ash rate response $(\mathrm{A} 0, \mathrm{~A} 10, \mathrm{~A} 20, \mathrm{~A} 30, \mathrm{~A} 40, \mathrm{~A} 50)$} \\
\hline Contrasts $^{\mathrm{x}}$ & NS & $\mathrm{L} * *$ & NS & $\mathrm{L}^{* *}, \mathrm{Q}^{* * *}$ & $\mathrm{~L} * * *, \mathrm{Q}^{* * *}$ & NS & NS & $\mathrm{L} * * *, \mathrm{Q}^{* * *}$ & $\mathrm{~L}^{* * *}, \mathrm{Q}^{* * *}$ & $\mathrm{~L} * * *, \mathrm{Q}^{* *}$ & $\mathrm{Q}^{*}$ \\
\hline
\end{tabular}

${ }^{\mathrm{z}}$ Fafard $3 \mathrm{~B}=100 \%$ Fafard 3B; peat-based substrate blends containing 0\% (A0, A0N), 10\% (A10), 20\% (A20), 30\% (A30), 40\% (A40), and 50\% (A50) pulp mill ash. All substrates contained $5.93 \mathrm{~kg} \cdot \mathrm{m}^{-3}$ Osmocote $(14 \mathrm{~N}-6.2 \mathrm{P}-11.6 \mathrm{~K})$ and $0.89 \mathrm{~kg} \cdot \mathrm{m}^{-3} \mathrm{Micromax}$ except A0N. A0 and A0N also contained $2.97 \mathrm{~kg} \cdot \mathrm{m}^{-3}$ dolomitic limestone.

'Tukey's honestly significant difference $(P=0.05, \mathrm{n}=5)$.

${ }^{x}$ Significant linear (L) or quadratic (Q) contrasts at $P \leq 0.05(*), 0.01(* *)$, or $0.001(* * *)$ across ash contents $(0 \%$ to $50 \%)$ in peat-based substrates $(\mathrm{A} 0$, A10, A20, A30, A40, A50).

NS = nonsignificant. 
to $60 \%$ compost in the growing substrate produced more dry matter in petunia and impatiens than substrates containing higher or lower proportions of compost in the blend (Moore, 2004). Study with spent mushroom compost showed that although it is possible to use relatively large amounts of spent mushroom compost in a container substrate, the amounts used in actual growing conditions is often in the range of $10 \%$ to $20 \%$, rarely exceeding $50 \%$ (Chong, 2005). Keeping the proportion of such amendments in a substrate blend relatively low can decrease the likelihood of developing excessively high $\mathrm{pH}$, EC, or both (Chong, 2005). For boiler ash, it appears blends of $20 \%$ ash or less in a peat-based substrate were suitable for marigold production. For other crops more sensitive to high $\mathrm{pH}$, blends containing $20 \%$ ash may be too high for optimal growth. Further work will need to be conducted to evaluate the growth response of a wide range of greenhouse crops on the substrate blend with addition of ash.

It is also of note that ash characteristics, including physical and chemical properties and nutrient concentrations, can vary among sources or batches of the same source, just as many other waste byproducts (Chong, 2005). For example, boiler ash samples tested by Muse and Mitchell (1995) had an average Ca carbonate equivalence of $37 \%$ and a range of $0 \%$ to $70.3 \%$. The variability in ash composition suggests it is of critical importance to maintain consistent sourcing and conduct proper testing before incorporating paper mill boiler ash into growing substrates. It is also important to choose wood ash originating from the burning of forest residues or untreated wood and to avoid using ashes from waste wood such as demolition wood, painted, or impregnated wood to avoid the possibility of heavy metal contamination (Demeyer et al., 2001).

\section{Literature Cited}

Bachman, G.R. and J. Metzger. 1998. The use of vermicompost as a media amendment. Proc. South. Nur. Assn. Res. Conf. 43:32-33.

Bilderback, T.E., W.C. Fonteno, and D.R. Johnson. 1982. Physical properties of media composed of peanut hulls, pinebark and peatmoss and their effects on azalea growth. J. Amer. Soc. Hort. Sci. 107:522-525.
Bugbee, G.J. and C.R. Frink. 1989. Composted waste as a peat substitute in peat-lite media. HortScience 24:625-627.

Chirenji, T. and L.Q. Ma. 2002. Impact of highvolume wood-fired boiler ash amendment on soil properties and nutrients. Commun. Soil Sci. Plant Anal. 33:1-17.

Chong, C. 2005. Experiences with wastes and composts in nursery substrates. HortTechnology 15:739-746.

Cole, D.M., J.L. Sibley, E.K. Blythe, D.J. Eakes, and K.M. Tilt. 2005. Effect of cotton gin compost on substrate properties and growth of azalea under differing irrigation regimes in a greenhouse setting. HortTechnology 15:145148.

Conover, C.A. and R.T. Poole. 1983. Sedge moss peat, solite, and Melaluca quinquenervia as potting medium components for shadehouse production of foliage plants. HortScience $18: 888-890$

Cox, M.S. 2001. The Lancaster soil test method as an alternative to the Mehlich 3 soil test method. Soil Sci. 166:484-489.

Demeyer, A., J.C. Voundi Nikana, and M.G. Verloo. 2001. Characteristics of wood ash and influence on soil properties and nutrient uptake: An overview. Bioresour. Technol. 77:287295.

Fain, G.B., C.H. Gilliam, and J.L. Sibley. 2006. Evaluation of an alternative, sustainable substrate for use in greenhouse crops. Proc. South. Nur. Assn. Res. Conf. 51:651-654.

Fain, G.B., C.H. Gilliam, J.L. Sibley, C.R. Boyer, and A.L. Witcher. 2008. WholeTree substrate and fertilizer rate in production of greenhousegrown petunia (Petunia $\times$ hybrida Vilm.) and marigold (Tagetes patula L.). HortScience 43:700-705.

Gruda, N. and W.H. Schnitzler. 2001. Physical properties of wood fiber substrates and their effect on growth of lettuce seedlings (Lactuca sativa L. var. capitata L.). Acta Hort. 548:415423.

Hidalgo, P.R., F.B. Matta, and R.L. Harkess. 2006. Physical and chemical properties of substrates containing earthworm castings and effects on marigold growth. HortScience 41:14741476.

Jackson, B.E., A.N. Wright, D.M. Cole, and J.L. Sibley. 2005. Cotton gin compost as a substrate component in container production of nursery crops. J. Environ. Hort. 23:118-122.

Jones, J.B. and W.J.A. Steyn. 1973. Sampling, handling, and analyzing plant tissue samples, p. 249-270. In: Walsh, L.M. and J.D. Beaton (eds.). Soil testing and plant analysis. Soil Sci. Soc. Am., Inc, Madison, WI.

Kenna, S.W. and C.E. Whitcomb. 1985. Hardwood chips as an alternative medium for container plant production. HortScience 20: 867-869.

Moore, K.K. 2004. Growth of bedding plants in substrates amended with compost and fertilized with three different release rates of a controlled-release fertilizer product. HortTechnology 14:474-478.

Muse, J.K. and C.C. Mitchell. 1995. Paper mill boiler ash and lime by-products as soil liming materials. Agron. J. 87:423-438.

Myers, N.L. and M.J. Kopecky. 1998. Industrial wood ash as a soil amendment for crop production. Tappi J. 81:123-130.

Owings, A.D. 1993. Cotton gin trash as a medium component in production of 'Golden Bedder' coleus. Proc. Southern Nursery Assn. Res. Conf. 38:65-66.

Rakala, R. and H.J. Jozefek. 1990. Effect of dolomite lime and wood ash on peat substrate and development of tree seedlings. Silva Fennica. 24:323-334.

Reed, D.W. (ed.). 1996. A grower's guide to water, media, and nutrition for greenhouse crops. Ball Publishing, West Chicago, IL.

Robbins, J.A. and M.R. Evans. 2008. Growing media for container production in a greenhouse or nursery, part II (physical and chemical properties). 18 Aug. 2008. <http://www.uaex.edu/Other _Areas/publications/PDF/FSA-6098.pdf/>.

Schuman, G.E., M.A. Stanley, and D. Knudsen. 1973. Automated total nitrogen analysis of soil and plant samples. Proc. Soil Sci. Soc. Amer. 37:480-481.

Scoggins, H.L. and M.W. van Iersel. 2006. In situ probes for measurement of electrical conductivity of soilless substrates: Effects of temperature and substrate moisture content. HortScience 41:210-214.

U.S. Environmental Protection Agency. 1993. Standards for the use or disposal of sewage sludge (40 Code of Federal Regulations Part 503). U.S. Environmental Protection Agency, Washington, DC

Vance, E.D 1996. Land application of wood-fired and combination boiler ashes: An overview. J. Environ. Qual. 25:937-944.

Wright, A.N., J.L. Sibley, and W. Lu. 2005. Evaluation of composted municipal waste as amendment to pine bark for use in container ornamental plants, p. 68-69. In: Midcap, J.T. (ed.). 2004 research reports. Center for Applied Nursery Research, Univ. Georgia.

Wright, R.D. and J.F. Browder. 2005. Chipped pine logs: A potential substrate for greenhouse and nursery crops. HortScience 40:15131515.

Yeager, T., C. Gilliam, T.E. Bilderback, D. Fare, A. Niemiera, and K. Tilt. 2007. Best management practices: Guide for producing nursery plants. Southern Nursery Assn., Atlanta, GA. 